\title{
Releasing Hormone Agonist Therapy
}

National Cancer Institute

\section{Source}

National Cancer Institute. Releasing Hormone Agonist Therapy. NCI Thesaurus. Code C15489.

The use of releasing hormone agonists to bind to specific receptors and ultimately downregulate the activity of its specific hormone. 